\title{
ディファレンスからシミラリティヘ
}

中島和彦

\section{From Ethnic Difference to Ethnic Similarity}

\author{
Kazuhiko NAKAJIMA \\ Drug Evaluation Committee, Japan Pharmaceutical Manufactures Associations, Torii Nihonbashi Bldg., \\ 3-4-1 Nihonbashi-honcho, Chuo-ku, Tokyo 103-0023, Japan
}

(Received October 10, 2008)

\begin{abstract}
It becomes the important issue for the medical supplies administration to solve the drug lag in our country. As means to overcome both the slow speed and high cost of clinical trial for new drug application in Japan, it seems useful to carry out clinical development simultaneously in East Asia countries such as China, Korea and Taiwan where it is thought that each country has similar ethnicity one another. When conducting simultaneous development with the same protocol in plural countries, it should be avoided that side effect develops abusively. In addition, both the effectiveness and safety expected after marketing should be secured in each country by a recommended amount of medicine for usage provided by simultaneous development between many countries. It is necessary for ethnic similarity to be shown so that development between the many countries in the same dosage is permitted at least. It is expected that the possibility of mutual utilization of clinical trial data of China, Korea and Japan will be shown by pharmacokinetics and pharmacodynamics examinations based on clinical test data of these countries by the Scientific Research funded by MHLW. On the other hand, it seems that it is meaningful and significant to examine the similarity at the gene level from various points of view. In order to give grounds for the validity of carrying out clinical trial in the same protocol in East Asia countries, it may be useful to examine genetic diversity of East Asia countries with plural heredity anthropological techniques such as heredity distance, and compare degree of the genetic diversity between the races of East Asia countries and that of other regions, for example, West Europe countries which have been recognized as one clinical trial field.
\end{abstract}

Key words — ethnic similarity; east asia country; heredity anthropological technique; ethnic difference; genetic diversity

\section{1. はじめに}

わが国におけるドラッグ・ラグ1)の解消が医薬品 行政の課題となっている. 医薬品市場としての魅力 度が低いこと, 承認審査行政のパフォーマンスが今 まで十分でなかったこと, ${ }^{2,3)}$ 治験環境が整っていな いためスピードとコストに難点があったこと, ${ }^{4)}$ な ぞの要因により，医薬品開発の場としてのわが国の 魅力度，言い換えると日本での開発の優先性が低か つたと考えられる。

治験のスピードとコストを解決する手段として, お互いに似通った民族で構成される地域での共同開 発が考えられる. 最近, 厚生労働省, 医薬品医療機

日本製薬工業協会・医薬品評価委員会（T103-0023 東 京都中央区日本橋本町 3-4-1 トリイ日本橋ビル) e-mail: nakajima.kazuhiko.bj@daiichisankyo.co.jp 本総説は, 日本薬学会第 128 年会シンポジウムS 33 で 発表したものを中心に記述したものである.
器総合機構（PMDA）が，中国，韓国など東アジ ア諸国での臨床研究，行政などの面での連携を志向 した 5 (6) 背景の 1 つとしてこれがあると推定される. 多国間の治験を進める場合, 倫理面での配慮は最 も留意すべきことであり，同一の用法・用量で開発 を進めることにより副作用がタだりに発現すること を回避することは重要なことであろう。また多国間 共同開発により得られた各国同一の推奨用法・用量 で，上市後，期待された有効性，安全性が各国で確 保されることも求められる。このような前提に立つ た場合に，同一の用法・用量での開発が許容される には民族的類似性としてどのような事項が検討され ているべきかについて考察したい.

2. 開発戦略のオプションと国際共同開発の現状 欧米の製薬企業が日本を含むグローバル開発にお いて用いた旧来的開発戦略の多くは，欧米で臨床開 発を先行開始し，少なくとも狙いとする製品コンセ 
プトを検証できたのちに, 初めて日本における臨床 開発が着手されるというプロセスであろう。この方 法では早くても前期第 II 相臨床試験が終了した段階 で日本において第 I 相臨床試験が始まることとなる ため, 日本における新薬の臨床導入がかなり遅くな ってしまう。また ICH E5 ガイドラインに基づくブ リッジング戦略による臨床開発では，海外データが 外挿できると判断された場合には日本の臨床試験を 省略できることから旧来的開発戦略に比べある程度 は開発期間を短縮できるものの，やはり日本の臨床 現場への新薬の導入は欧米より遅れてしまうことに なる。欧米に遅れないためには日本が開発初期から 国際共同治験に参加していくことが必要である7 (Fig. 1).

グローバルメガ企業が進めてきた国際共同開発 は, 治験を欧米だけでなく, 南米, 南アフリカ, 東 アジアなどで基本的には同じプロトコールで実施し ている. ${ }^{8)}$ 言い換えると用法・用量に関し民族差は 全く眼中にないかのごとき開発方法を取っている. また東アジア地域の諸国が開発の途中から参加する 場合，その多くは，欧米で検討・決定された用量で 第 III 相臨床試験あるいは後期第 II 相臨床試験が実施 されている。昂日本の規制当局が重視する「わが国 での至適用量」10)という考え方に東アジア諸国の規 制当局は治験段階ではあまり拘泥していないのでは ないかとも思われる. ${ }^{9)}$ 最も，わが国の「至適用量」 という表現での求め方と欧米の「推奨用量」という 表現での求め方とから推量すると，わが国の「こだ わる民族性」がうかがわれるように思う。わわれは もつと肩の力を抜いてもよいのではないだろうか.

\section{3. 医薬品の用量の現状と民族的要因}

医薬品の 1 日の最大用量を循環器用薬ではス夕チ ン類，ACE 阻害薬，カルシウム拮抗薬を，また消 化器用薬ではプロトンポンプ阻害薬, $\mathrm{H}_{2}$ 受容体拮 抗薬について整理してみた。その結果かなりの薬剂 において，日本の用量が欧米の $2 / 3-1 / 2$ であること が分かる (Fig. 2)。この用量の違いがなにに由来 するかは不明である，恐らくその理由の 1 つは欧米 人と日本人との体格の違いであろう。また体格以外 の民族的特性の違いも関与している可能性もある. しかし安全性の確保こいう観点で少しでも低い用量 を選択するという指向性がわが国には存在している ようにも思われる。
有効性と安全性に係わる因子と民族性について考 察してみる，薬物が投与され，有効性，安全性を示 すことに大きく係わるものは，1 つには標的臟器や 標的細胞での薬物濃度（未変化体，活性代謝物）で あろう。これに及ぼす主な因子としては，体格，薬 物代謝酵素，薬物輸送等が挙げられる。他の 1 つは 標的臓器や標的細胞での薬物に対する感受性であろ う。これらの因子は民族的背景に関係していること が考えられる（Fig. 3）。このような因子の民族間 の違いが前述の日本と欧米との用量の違いの理由と して考えられる.

4. 東アジアにおける治験の現状と東アジアにお けるコラボレーションへの期待

日本の治験の現状を端的に述べると, 進渉速度が 一般には欧米に比し遅く, 開発コストが高額であ る. ${ }^{11)}$ 一方，アジア諸国では様々な疾患において症 例の組み込み速度は欧米に匹敵する。またアジア諸 国の開発コストは数年前の調査では日本の 1/4-1/3 であり, ${ }^{12)}$ 最近中国ではやや上昇しているようでは あるが，それでも全般に日本に比し相当に低い。し たがって民族的に日本人と類似していると感じられ る東アジアの国ぐににおけるコラボレーション，す なわち東アジア地域での国際共同開発が円滑に実施 できれば，開発候補品の臨床評価の効率化という点 で各国相互に有益である。ここで有効性，安全性に 影響する用法・用量を各国同一で開発が進められれ ば一層の効率化が図られることとなる。

厚生労働省, PMDA が, 中国, 韓国など東アジ ア諸国での臨床研究, 行政などの面での連携を志向 した ${ }^{5,6}$ 背景の 1 つとしこれがあると推定され る. 東アジアでの共同開発の可能性，すなわち東ア ジア諸国での治験データの相互活用の可能性を探る ために, 2007 年より国立医薬食品衛生研究所の頭 金正博室長を主任研究者とする厚生労働科学研究班 「日中韓の臨床データにおける民族差要因を評価す るための研究班」が立ち上げられ，治験デー夕に 基づく pharmacokinetics (PK), pharmacodynamics (PD) の両面からの科学的検討が進められている. これにより少なくとも日中韓 3 国での治験データの 相互活用の可能性が示され，さらにアジア地域での 国際共同治験を実施する際の留意点，例えば薬剤特 性に応じた臨床評価手順といったものが整理され， アジア地区における国際共同治験の効率化が図られ 


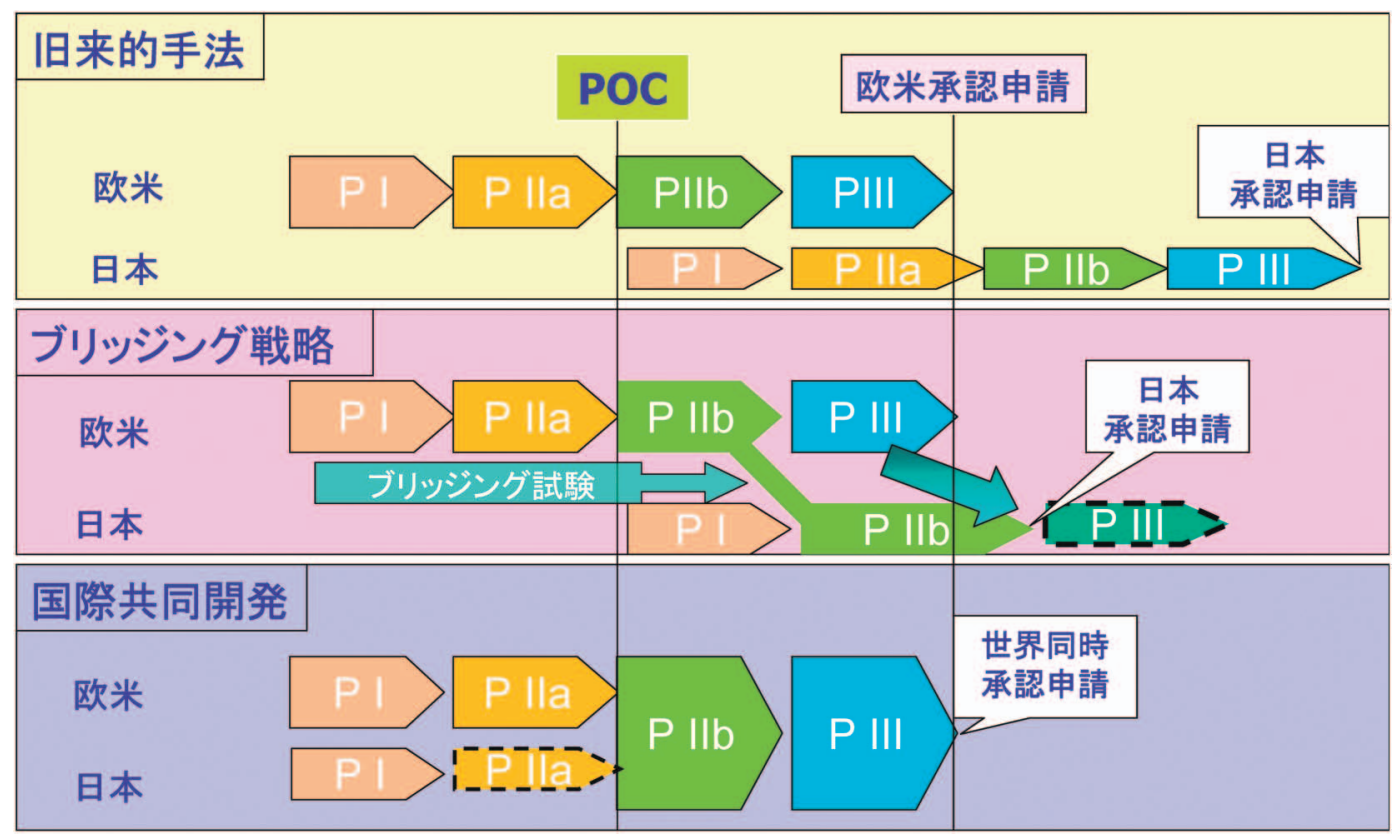

Fig. 1. Options of Development Strategy

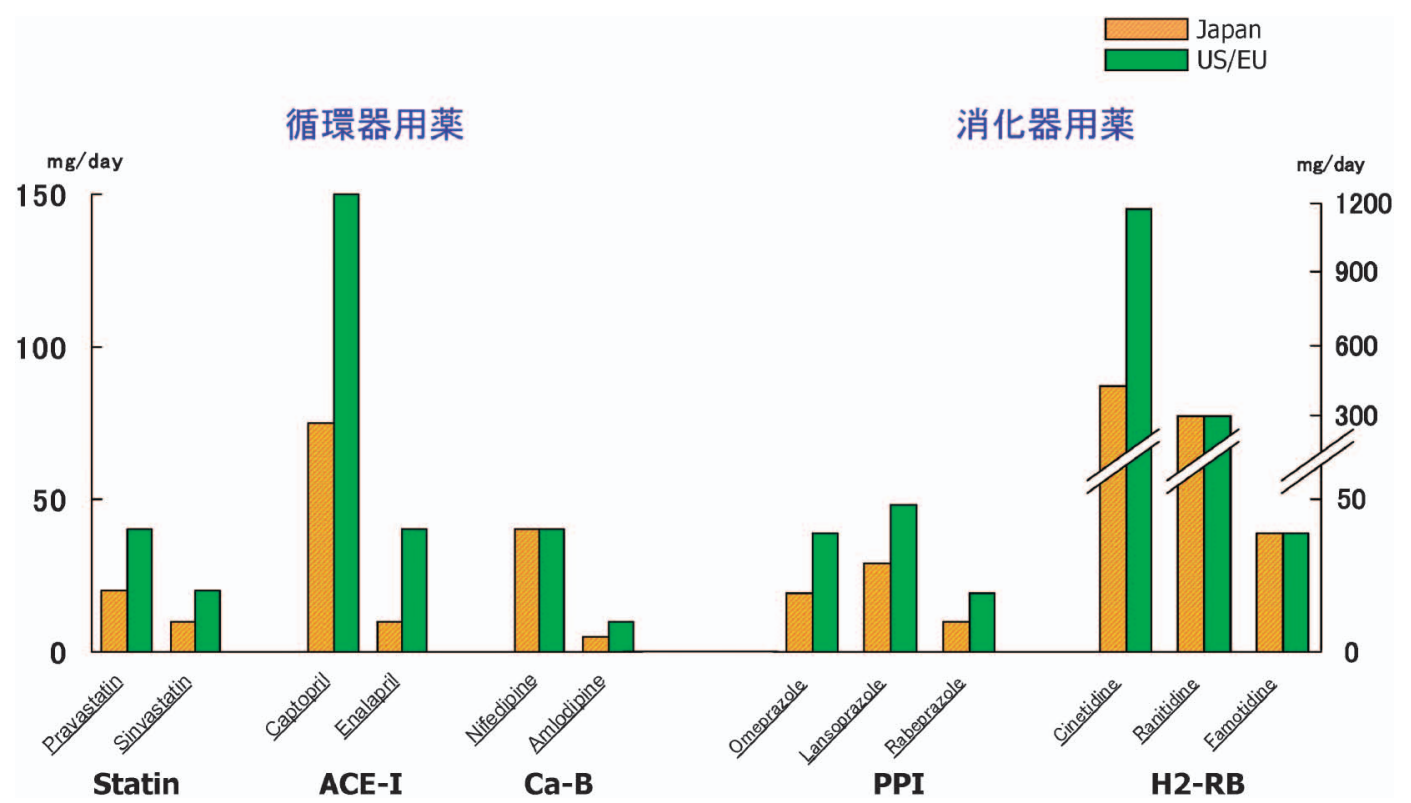

Fig. 2. Comparison of Maximal Daily Dosage between Japan and US/EU

ることを期待したい.

\section{5. 東アジア諸国の民族的類似性の現状}

東アジア諸国の民族的類似性に関するデータにつ いて概観する。

日本人と中国人の身長・体重，寿命，死因につい て比較したデータがある。寿命，死因は香港との比 較であり，身長・体重及び寿命については男女毎に データがあるが，この範囲では日本人と中国人とで
相当程度に近似している (Fig. 4). ${ }^{13)}$

またヒト・ゲノムにおける対立遺伝子頻度と単一 塩基多型頻度との関係を民族間で比較したデータで は，中国人（北京在住の漢民族）と日本人（東京在 住）とは $2 つ の$ 頻度関係が相当に近似しており，白 人やアフリカ人とは明らかに異なることが示されて いる (Fig. 5). ${ }^{14)}$

現代人が 15-20 万年前にアフリカで誕生後に地球 


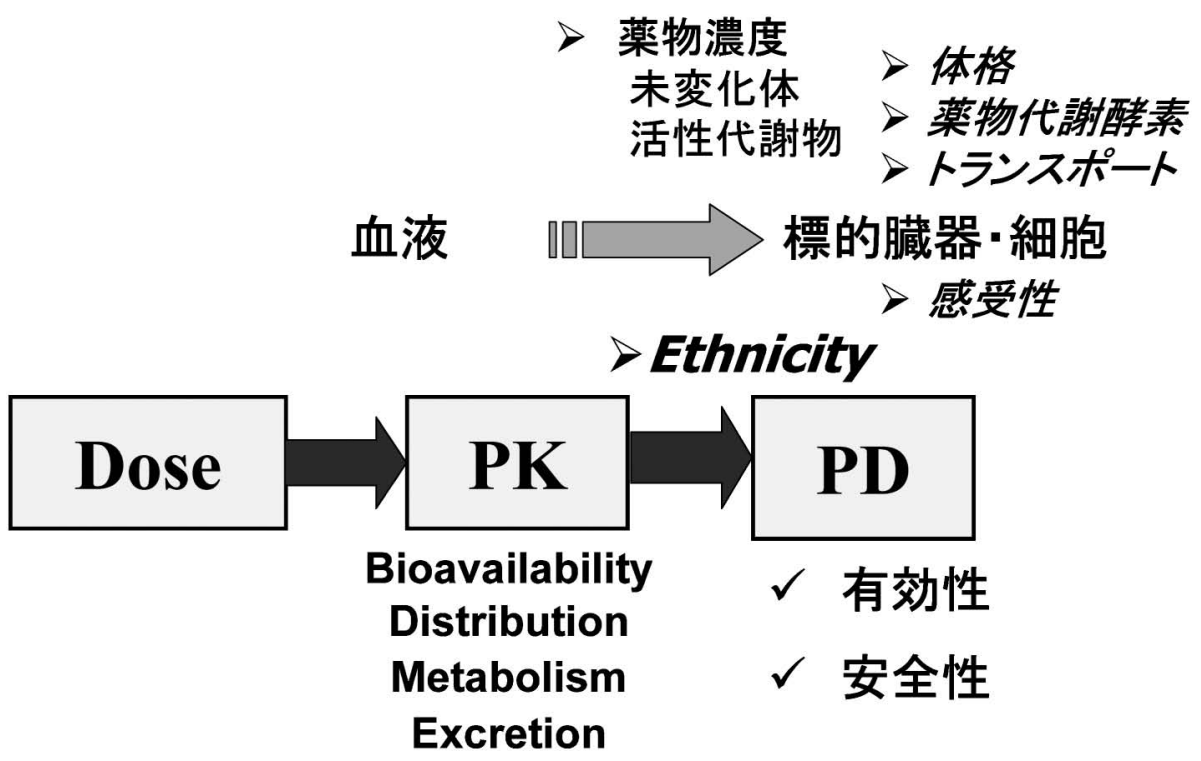

Fig. 3. Internal Factors Influencing on Drug Effectiveness and Drug Safety

身長·体重

\begin{tabular}{|c|c|c|c|c|c|}
\hline \multicolumn{2}{|c|}{} & \multicolumn{2}{c|}{ 男性 } & \multicolumn{2}{c|}{ 女性 } \\
\cline { 3 - 6 } \multicolumn{2}{|c|}{} & 身長 & 体重 & 身長 & 体重 \\
\hline 中国人 & Adult & $169.7 \mathrm{~cm}$ & $67.7 \mathrm{~kg}$ & $158.6 \mathrm{~cm}$ & $59.6 \mathrm{~kg}$ \\
\hline \multirow{2}{*}{ 日本人 } & 40 's & $169.3 \mathrm{~cm}$ & $68.2 \mathrm{~kg}$ & $155.7 \mathrm{~cm}$ & $54.5 \mathrm{~kg}$ \\
\cline { 2 - 6 } & 50 's & $165.7 \mathrm{~cm}$ & $64.6 \mathrm{~kg}$ & $153.0 \mathrm{~cm}$ & $54.6 \mathrm{~kg}$ \\
\hline
\end{tabular}

寿命

\begin{tabular}{|c|c|c|c|}
\hline \multicolumn{2}{|c|}{ 日本 } & \multicolumn{2}{c|}{ 香港 } \\
\hline 男性 & 女性 & 男性 & 女性 \\
77.6 & 84.6 & 78.0 & 83.9 \\
\hline
\end{tabular}

\begin{tabular}{|c|c|c|c|c|c|}
\hline & 1 & 2 & 3 & 4 & 5 \\
\hline 香港 & $\begin{array}{c}\text { 癌 } \\
(33.0 \%)\end{array}$ & $\begin{array}{c}\text { 心疾患 } \\
(16.3 \%)\end{array}$ & $\begin{array}{c}\text { 脳疾患 } \\
(10.5 \%)\end{array}$ & $\begin{array}{c}\text { 肺炎 } \\
(8.9 \%)\end{array}$ & $\begin{array}{c}\text { 突然死/ } \\
\text { 中毒 } \\
(5.6 \%)\end{array}$ \\
\hline 日本 & $\begin{array}{c}\text { 癌 } \\
(31.0 \%)\end{array}$ & $\begin{array}{c}\text { 心疾患 } \\
(15.3 \%)\end{array}$ & $\begin{array}{c}\text { 脳疾患 } \\
(13.6 \%)\end{array}$ & $\begin{array}{c}\text { 肺炎 } \\
(8.8 \%)\end{array}$ & $\begin{array}{c}\text { 突然死 } \\
(4.1 \%)\end{array}$ \\
\hline
\end{tabular}

Source: J. Clin. Therap. Med., 22, 597-606 (2006).

Fig. 4. Comparison between Chinese and Japanese on Height, Weight, Life Span, and Cause of Death

上の各地に拡散していった経路がヒト化石や遺伝子 の研究から推定されている.これによるとヒ卜は東 アジアではインドシナ半島からモンゴル, 中国, 韓 国を経て日本に辿り着いたようである。

「遺伝距離」という指標を用いてヒト集団間の遺 伝的な近縁関係を位置付ける研究手法がある。 ある 研究では血液型や赤血球中の䤉素類の計 12 個の遺 伝子座における対立遺伝子の頻度デー夕を基に「遺 伝距離」を推定し, 各集団間の遺伝的な違いの程度
を分析している. 各集団間の枝の長さが相対的な違 いの程度を示すことになる，この成績でみると，中 国北部の中国人，アイヌ人，朝鮮人は日本人にかな り近いことになり, ほかの集団群とは別の集団群を 形成している (Fig. 6). 15)

7 種の標準薬物パネルに対する cytochrome P450 の活性と genotype の関係を日本人 (日本本国在住, 海外在住一世・三世), 韓国人, 中国人, 白人で検 討した成績では，概括的にみて日本人，韓国人，中 

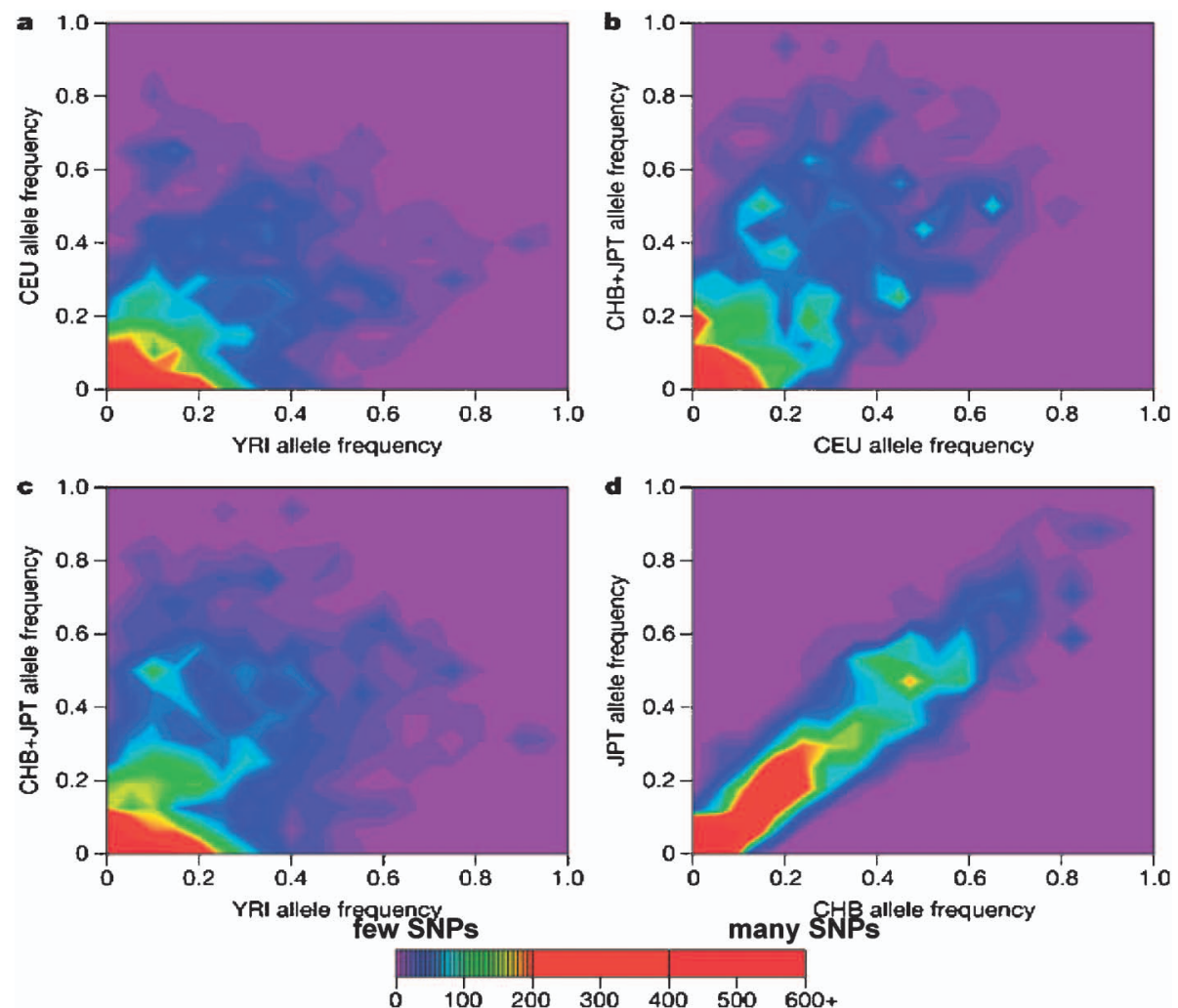

Source: Nature, 437, 1300-1320 (2005).

Fig. 5. Correlations on Allele Frequency and SNPs Frequency between Races

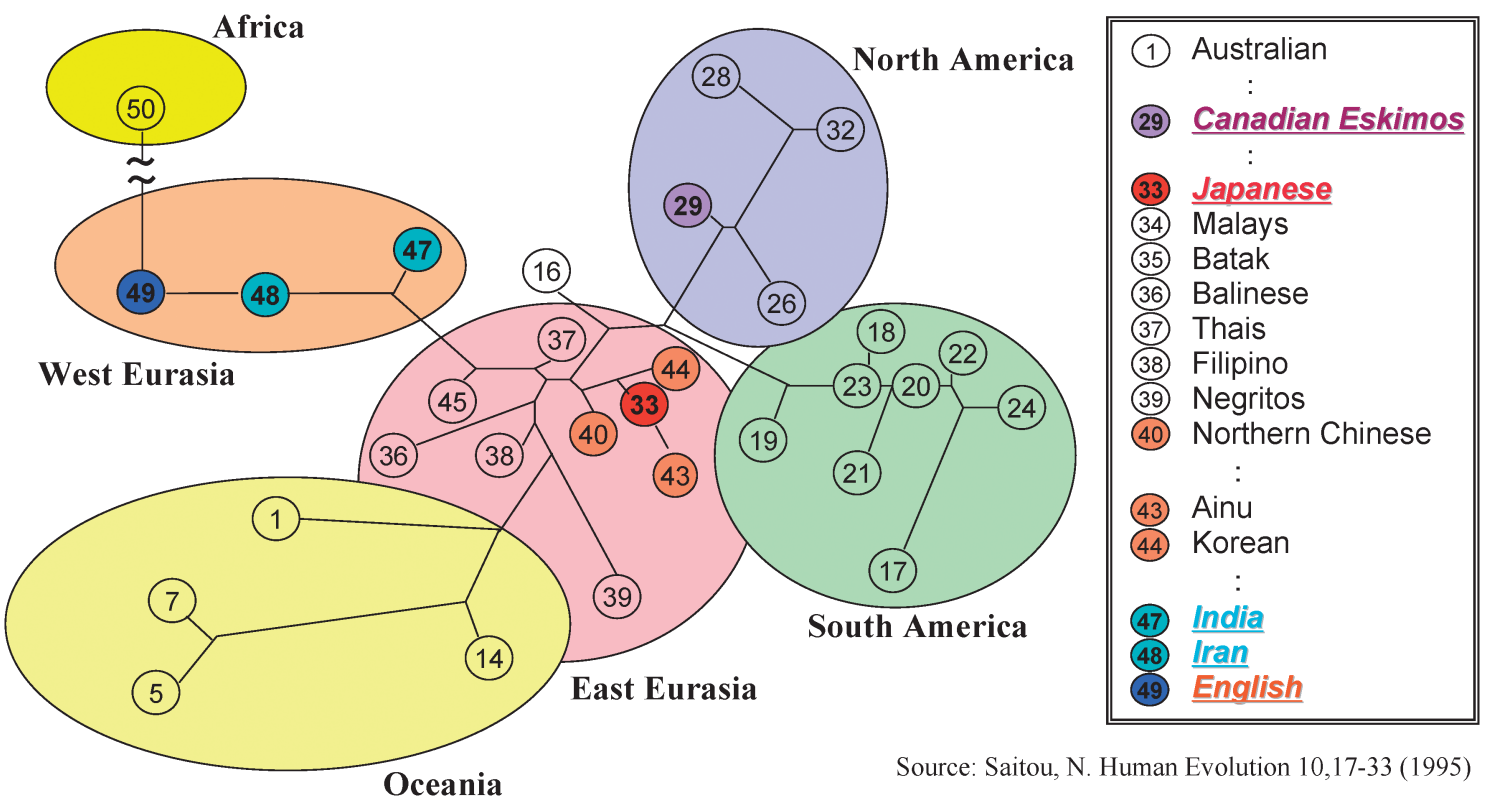

Fig. 6. Hereditary Closely Related Relations between the Homo Sapiens Groups by the Heredity Distance

国人では同等の血清中薬物濃度，薬物代謝プロフ イールを期待し得ることが示されている（Fig. 7). 16)
さて先に述べたごとく，グローバルメガ企業が進 めてきた国際共同治験では，民族差を考慮しないか のごとき開発手法を取つてきた。最近になって欧米 


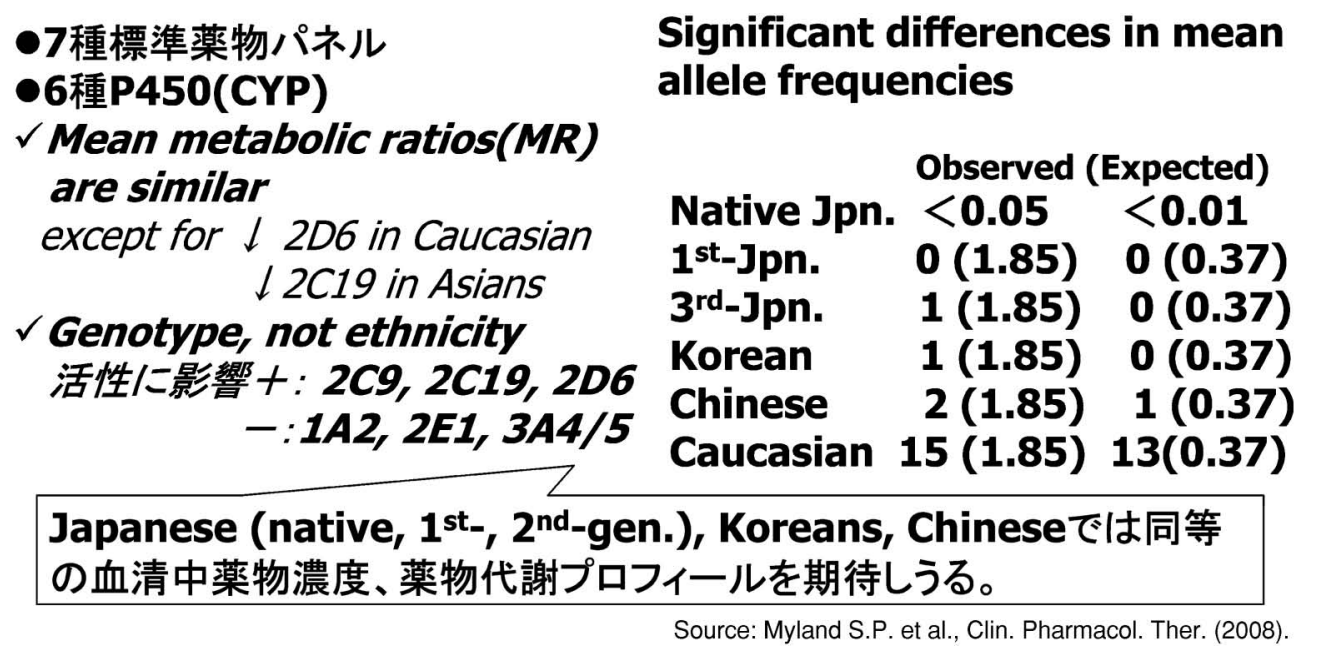

Fig. 7. Comparison of Activity and Genotype of Major Cytochrome P450s with Japanese (native, 1st-, 3rd- gen.), Chinese and Causasian

とも，民族的あるいは地域的な差異を考慮する必要 性を認識しはじめているようである. ${ }^{17,18)}$. EU に おいては他地域の臨床試験デー夕を EU 内に外挿す る際の考え方を示している. ${ }^{18)}$ しかし少なくとも EU 域内，特に西ヨーロッパ諸国での臨床試験の実 施あるいは臨床試験成績の取り扱いについて特段の 考え方は示されていない.

6. おわりに

日中韓を中心とした東アジア諸国での国際共同治 験を実施するには，東アジア諸国を同一の治験フ イールドとして扱ってよいことが前提となる．東ア ジアで実施された治験は GCPに準拠して実施さ れ，この地域での治験成績に基づく医薬品が欧米で 承認された実績を踏まえると，治験の質については 問題がないものと考えられる. ${ }^{9)}$ むろ PK, PD 面 での同質性が課題となる。したがって厚生労働科学 研究班にて治験デー夕に基づき PK, PD 面から治 験デー夕の相互活用性などが検討されることは意義 深いことである.

先に述べたごとく，少なくとも臨床開発段階にお いて副作用がいたずらに発現するといったことがな いことをある程度保証できていることが望まれる。 言い換えると東アジア諸国における民族性に類似性 があることを包括的に確認しておくことが必要とな る。そういう意味では前述の研究班での取り組みの 一方で，遺伝子レベルでの類似性を多角的に検討し ておくことも意義深いと思われる.

これらの検討のなかで，異なる地域との遺伝的多
様性の比較により，東アジア地域を 1 つの治験フ イールドとして捉えることの妥当性を検討すること もできるのではないかと考える，すなわち，遺伝距 離など複数の遺伝人類学的手法を用い，東アジア諸 国の民族間の遺伝的多様性の程度を，例えば従来 1 つの治験フィールドとして認識されている西ヨーロ ッパ諸国における遺伝的多様性の程度を比較するこ とは，東アジア諸国において同一のプロトコルで治 験を実施することの妥当性を考える上で有用ではな いかと考える．またこの検討手法により東アジア諸 国における民族間の遺伝的多様性が西ヨーロッパ諸 国における民族間の遺伝的多様性と同程度の広がり であることが複数の方法により示されれば，やや乱 暴な推論ではあるが，東アジア地域内における副作 用発生に係わる均質性について，PD に基づく副作 用発生メカニズムの場合のみならず，特異的副作用 発生メカニズムをも包含した保証を傍証的に与える のではないだろうか.

\section{REFERENCES}

1) Fukuhara H., OPIR Research Paper Series, No. 31 (2006).

2) Asaka O., Kawakami H., Ono S., OPIR Research Paper Series, No. 25 (2005).

3) Yasuda K., Ono S., OPIR Research Paper Series, No. 37 (2007).

4) Kusuoka H., Consolidated Report of Medical Economic Studies about Clinical Trial Cost supported by MHLW Scientific Research 
Funds Subsidy Special Business in 2005FY (2006) .

5) Joint Statement of the First Tripartite Health Ministers Meeting among the People's Republic of China, Japan and the Republic of Korea (2007).

6) East Asian Pharmaceutical Regulatory Symposium 2008 hosted by MHLW \& PMDA (2008).

7) Basic Principles on Global Clinical Trials, Notification from Director of Evaluation and Licensing Division, Pharmaceutical and Food Safety Bureau, MHLW, No. 0928010 (2007).

8) Ishibashi K., OPIR News, No. 21, 18-21 (2006) .

9) Clinical Trial Environment in Asia - South Korea, Taiwan, Singapore, China-, The Asia Delegation Report, Drug Evaluation Committee, JPMA (2008).

10) MHLW, 1st The Meeting to Study How to Offer More Effective and Safer Medicines Rapidly, Material No. 3 (2006).
11) Urushidani A., Pharm. Mon., 47, 2239-2250 (2005).

12) Recent Clinical Trial Environment in Asia, TF5-2 Report, Clinical Evaluation Subcommitte, Drug Evaluation Committee, JPMA (2005) .

13) Kageyama S., J. Clin. Ther. Med., 22, 597606 (2006).

14) The International HapMap Consortium, $\mathrm{Na}$ ture, 437, 1300-1320 (2005).

15) Saito N., Hum. Evol., 10, 17-33 (1995).

16) Myrand S. P., Sekiguchi K., Man M. Z., Lin X., Tzeng R.-Y., Teng C.-H., Hee B., Garrett M., Kikkawa H., Lin C.-Y., Eddy S. M., Dostalik J., Mount J., Azuma J., Fujio Y., Jang I.-J., Shin S.-G., Bleavins M. R., Williams J. A., Paulauskis J. D., Wilner K. D., Clin. Pharmacol. Ther., 84, 347-361 (2008).

17) Anello C., O'Neil R. T., Dubey S., Stat. Methods. Med. Res., 14, 303-318 (2005).

18) EMEA/CHMP/EWP/7799 (2007). 